УДК 378.126

DOI: https://doi.org/10.35619/iiu.v0i9.135

Галецький Сергій викладач кафедри міжнародної мовної комунікації Національний університет «Острозька академія»,

м. Острог, Україна

ORCID: 0000-0001-6532-3108

e-mail: sergii.galetskyi@oa.edu.ua

\title{
КОМУНІКАТИВНА КОМПЕТЕНТНІСТЬ МАЙБУТНІХ ВИКЛАДАЧІВ ІНОЗЕМНИХ МОВ ЯК ПРЕДМЕТ НАУКОВИХ ДОСЛІДЖЕНЬ
}

Анотація. У статті розглянуто підходи до трактування комунікативної компетентності. Зазначено, що комунікативна компетентність $\epsilon$ складовою професійно-педагогічної компетенції викладачів англійської мови. Рівень сформованості знань, комунікативних навичок, умінь майбутніх фахівців здійснює визначальний вплив на здатність реалізувати їх у педагогічному процесі та встановленні контактів у вихованні сучасної молоді та в успішній діяльності в бізнес-середовищі.

3'ясовано спільні і відмінні риси у таких ії складових, як «компетенція» і «компетентність», «спілкування» i «комунікація». Наголошено на необхідності більш чіткому використанні таких загальнонаукових визначень, як «термін», «поняття», «категорія». Важливо розрізняти у внутрішній організації явища співвідношення понять «загальне» i «часткове». Саме воно характеризує розмежування змісту явища і форми його прояву не тільки в якості внутрішньої субординації, а й їх діалектичної взаємодії. Процес розвитку явища проявляється в нерозривності та взаємопереході однієї категорії в іншу.

Зроблено висновок, що відсутність узгодженості в підходах вчених щодо трактування сутності, складових, співвідношення багатьох понять часто пов'язано із нечітким вирізненням у внутрішній організації явища співвідношення понять «загальне» і «часткове».

Ключові слова: комунікативна компетентність, компетентність, компетенція, спілкування, комунікація, термін, поняття, категорія.

Постановка проблеми. Динамічний науково-технічний i суспільний розвиток, сучасний комп'ютерний світ, глобалізація соціально-економічного простору, значна інтенсивність ділових контактів не лише розширюють обрії можливостей для людини, а й ставлять нові вимоги до іiі освітнього рівня, стимулюють подальше удосконалення форм, методів, прийомів, технологій передачі знань. Сучасній освіті притаманні процеси гуманізації, інформатизації, глобалізації, інтеграції. Запровадження в навчальний процес загальної та професійної освіти компетентнісного підходу переакцентовує увагу 3 процесу накопичення нормативно визначених знань, навичок, умінь (знаннєвої парадигми у розвитку освіти) на розвиток компетентностей особистості з метою набуття нею вмінь застосовувати їх на практиці, здатності до самовдосконалення, самоосвіти (діяльнісна парадигма).

Аналіз останніх досліджень 3 проблеми. Засади «компетентнісної освіти» розроблено у США в 60 -х роках XX ст. У 80 -х роках їх запроваджено до освітніх програм Великобританії та Німеччини, Канади та інших країн (Лейко, 2013, с. 129). Основні положення викладено в «Стратегії реформування 
вищої освіти в Україні до 2020 року» (Стратегія реформування вищої освіти в Україні до 2020 року). Різноманітні аспекти цієї проблематики представляють науковий інтерес для багатьох дослідників, а саме: В. І. Байденка, М. С. Головань, К. В. Рудніцької, І. А. Зимньої, Н. В. Кузьміної, В. О. Кучай, С. В. Лейко, А. К. Маркової, О. В. Овчарука, А. В. Хуторського та ін. Зокрема, до проблеми комунікативної компетентності зверталися такі вчені, як О. Баранніков, О. Овчарук, Дж. Равен, О. Савченко (з позиції компетентісної освіти), Б. Ананьєв, Л. Виготський, В. Давидов, С. Рубінштейн (теорія діяльності й розвитку особистості), Ф. Бацевич, О. Пометун (комунікативне навчання). Проте на сьогодні недостатньо досліджень, присвячених розгляду сутності комунікативної компетентності майбутніх викладачів іноземних мов через з'ясування діалектики взаємодії загального і відмінного у таких іiі складових, як «компетенція» i «компетентність», «спілкування» i «комунікація».

Метою статті $\epsilon$ характеристика комунікативної компетентності майбутніх викладачів іноземних мов як предмету наукових досліджень.

Виклад основного матеріалу дослідження. Фундаментальними засадами компетентнісного підходу в освіті $€$ поняття компетенції i компетентності, тому що в умовах сьогодення формуються нові вимоги до професійного та культурного рівня спеціалістів. Це стосується й підготовки викладачів англійської мови, чия професійна діяльність безпосередньо пов'язана із спілкуванням 3 аудиторією. Комунікативна компетентність $\epsilon$ складовою їх професійно-педагогічної компетенції. Рівень сформованості знань, комунікативних навичок, умінь майбутніх фахівців здійснюватиме визначальний вплив на здатність реалізувати їх у педагогічному процесі, встановленні контактів й вихованні сучасної молоді та в успішній діяльності в бізнес-середовищі. Постійне підвищення професійної майстерності, особистої комунікативної активності є вимогою часу. Завдяки комунікаціям передається інформація, встановлюються ділові та особисті контакти, забезпечується професійне та ділове взаєморозуміння, формується нове мислення, навички, знання, уміння, потреби.

Нові завдання засвідчують потребу в більш докладному розгляді теоретико-методологічних засад дослідження сутності комунікативної компетентності через з'ясування діалектики взаємодії загального і відмінного у таких іiі складових як «компетенція» i «компетентність», «спілкування» i «комунікація» тощо. Важливо встановити взаємозв'язок між ними та виявити їх розмежування. Водночас не можна не звернути увагу на те, що доволі часто в наукових публікаціях цієї проблематики прослідковується нечіткість використання таких загальнонаукових визначень, як «термін», «поняття», «категорія».

Отже, «термін» - слово або словосполучення, що означає чітко окреслене спеціальне поняття (Яременко, Сліпушко, 2004, с. 524). «Поняття» - одна 3 форм мислення, результат узагальнення суттєвих ознак об'єкта (Яременко, Сліпушко, 2004, с. 794). Найбільш високий рівень узагальнення характеризує «категорія» як «основне логічне поняття, що відображає найзагальніші закономірні зв'язки й відношення, які існують у реальній дійсності» (Яременко, Сліпушко, 2004, с. 319).

Також важливо розрізняти у внутрішній організації явища співвідношення понять «загальне» i «часткове». Саме воно характеризує 
розмежування змісту явища i форми його прояву не тільки в якості внутрішньої субординації, а й їх діалектичної взаємодії. У змісті проявляється «суть, внутрішня особливість, мета, призначення чогось» (Яременко, Сліпушко, 2004, с. 769). Зміст, не зважаючи на те, що й відображається у конкретній формі, проте може бути ширшим за неї. Тому що форма $\epsilon$ «обрисом, контуром, зовнішніми межами, типом, способом організації чогонебудь, зовнішнім виявом явища» (Яременко, Сліпушко, 2004, с. 665). Форма може й неповністю відображати зміст. Процес розвитку явища проявляється в нерозривності та взаємопереході однієї категорії в іншу.

Саме це зумовлює відсутність узгодженості в підходах вчених щодо трактування сутності, складових, співвідношення багатьох понять. Зокрема, це стосується таких понять, як «компетенція» $\mathrm{i}$ «компетентність». На неоднозначність, багатоваріантність трактування, їхню багатокомпонентну структуру звертали увагу в своїх працях М. С. Головань, В. О. Калініна, О. В. Кучай, С. В. Лейко, Н. В. Нагорна, М. Ю. Онищенко, Н. М. Перевознюк, Г. Г. Руденко, А. В. Хуторський та ін. 3 огляду на це можна навести наступні погляди деяких дослідників щодо змісту аналізованих дефініцій (табл. 1).

Таблиця 1

\section{Тлумачення понять «компетенція» $\mathbf{i}$ «компетентність»} у науковій літературі

\begin{tabular}{|c|c|c|c|}
\hline \multicolumn{2}{|c|}{ Визначення суті поняття «компетенція» } & \multicolumn{2}{|c|}{ Визначення суті поняття «компетентність» } \\
\hline Автор, джерело & Визначення & Автор, джерело & Визначення \\
\hline $\begin{array}{l}\text { Новий } \\
\text { тлумачний } \\
\text { словник } \\
\text { української мови } \\
\text { (Яременко, } \\
\text { Сліпушко, 2004, } \\
\text { с. 874) }\end{array}$ & $\begin{array}{l}\text { Компетенція - добра } \\
\text { обізнаність із чим- } \\
\text { небудь, } \\
\text { повноважень }\end{array}$ & $\begin{array}{l}\text { Великий } \\
\text { тлумачний } \\
\text { словник сучасної } \\
\text { української мови } \\
\text { (Бусел та ін., } \\
2003, \text { с. 560) }\end{array}$ & $\begin{array}{l}\text { Компетентність } \\
\text { поінформованість, } \\
\text { обізнаність, } \\
\text { авторитетність }\end{array}$ \\
\hline $\begin{array}{l}\text { М. Ю. Онищенко } \\
\text { (Онищенко, } \\
2017, \text { с. } 110)\end{array}$ & $\begin{array}{l}\text { Компетенція } \\
\text { загальна здатність } \\
\text { особи, що базується } \\
\text { на знаннях, досвіді, } \\
\text { цінностях } \\
\text { здібностях, які набуті } \\
\text { завдяки навчанню }\end{array}$ & $\begin{array}{l}\text { А. М. Новиков } \\
\text { (Новиков, 2013, } \\
\text { с. } 80)\end{array}$ & $\begin{array}{l}\text { Компетентність } \\
\text { здатність (готовність) } \\
\text { людини до практичноі } \\
\text { діяльності і вирішення } \\
\text { проблем на основі } \\
\text { набутого } \\
\text { досвіду, життєвого } \\
\text { цінностей, схильностей } \\
\text { та здібностей }\end{array}$ \\
\hline $\begin{array}{l}\text { О. В. Кучай } \\
\text { (Кучай, 2009, с. } \\
\text { 131) }\end{array}$ & $\begin{array}{l}\text { Компетенція } \\
\text { сукупність } \\
\text { взаємопов'язаних } \\
\text { якостей особистості } \\
\text { (знання, уміння, } \\
\text { навички, способи } \\
\text { діяльності), що } \\
\text { задаються до певного } \\
\text { кола предметів і } \\
\text { процесів } \\
\text { необхідних та } \\
\text { якісної, продуктивної } \\
\text { діяльності щодо них }\end{array}$ & $\begin{array}{l}\text { Національний } \\
\text { освітній } \\
\text { глосарій: вища } \\
\text { освіта } \\
\text { (Кремень та ін., } \\
2014 \text {, с. 28-29) }\end{array}$ & $\begin{array}{l}\text { Компетентність } \\
\text { динамічна комбінація } \\
\text { знань, умінь } \\
\text { практичних навичок, } \\
\text { способів м мислення, } \\
\text { професійних, } \\
\text { світоглядних } \\
\text { громадянських } \\
\text { якостей, морально- } \\
\text { етичних цінностей, яка } \\
\text { визначає здатність } \\
\text { особи } \\
\text { здійснювати }\end{array}$ \\
\hline
\end{tabular}




\begin{tabular}{|c|c|c|c|}
\hline & & & $\begin{array}{lr}\text { професійну } & \text { та } \\
\text { подальшу } & \text { навчальну } \\
\text { діяльність } & \text { i } \\
\text { результатом навчання }\end{array}$ \\
\hline $\begin{array}{l}\text { С. В. Лейко } \\
\text { (Лейко, 2013, } \\
\text { c. 133) }\end{array}$ & $\begin{array}{l}\text { Компетенція } \\
\text { визначається певною } \\
\text { організацією, } \\
\text { установою, } \\
\text { державою як наперед } \\
\text { задана вимога до } \\
\text { знань, } \\
\text { навичок, умінь, } \\
\text { повинна волим } \\
\text { особистість } \\
\text { успішної діяльності в } \\
\text { межах тієї сфери, де } \\
\text { ця діяльність буде } \\
\text { здійснюватися. } \\
\text { Компетенція } \\
\text { пов’язана з певним } \\
\text { видом діяльності. }\end{array}$ & $\begin{array}{l}\text { А.В. Хуторський } \\
\text { (Хуторський, } \\
\text { 2003, с. 132) }\end{array}$ & $\begin{array}{l}\text { Компетентність } \\
\text { поєднання відповідних } \\
\text { знань і здібностей, що } \\
\text { дають підставу } \\
\text { обгрунтовано судити } \\
\text { про цю сферу й } \\
\text { ефективно діяти в ній; } \\
\text { володіння людиною } \\
\text { відповідною } \\
\text { компетенцією, що } \\
\text { включає його особисте } \\
\text { ставлення до неї та } \\
\text { предмета діяльності }\end{array}$ \\
\hline $\begin{array}{l}\text { О. М. Марущак } \\
\text { (Марущак, 2016) }\end{array}$ & $\begin{array}{l}\text { Компетенція } \\
\text { єдність теоретичних } \\
\text { знань, практичних } \\
\text { навичок і } \text { вмінь, } \\
\text { набутих у процесі } \\
\text { навчання, } \\
\text { особистісних } \\
\text { здібностей суб'єкта, } \\
\text { які складають його } \\
\text { готовність та } \\
\text { загальну здатність } \\
\text { діяти у у певній } \\
\text { професійній сфері. }\end{array}$ & $\begin{array}{l}\text { В. О. Калінін } \\
\text { (Калінін, 2005, с. } \\
\text { 8) }\end{array}$ & $\begin{array}{lr}\text { Компетентність } & - \\
\text { характеризує і визначає } \\
\text { рівень професіоналізму } \\
\text { особистості, а } \\
\text { досягнення } \\
\text { відбувається } \\
\text { здобуття необхерез } \\
\text { компетенцій, } \\
\text { складають що } \\
\text { професійної підготовки } \\
\text { фахівці }\end{array}$ \\
\hline $\begin{array}{l}\text { М. С. Головань } \\
\text { (Головань, с. 3) }\end{array}$ & 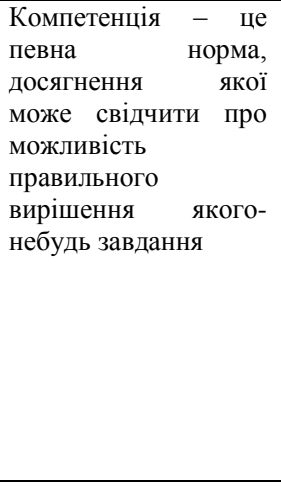 & $\begin{array}{l}\text { С. В. Лейко } \\
\text { (Лейко, 2013, } \\
\text { c. 133) }\end{array}$ & 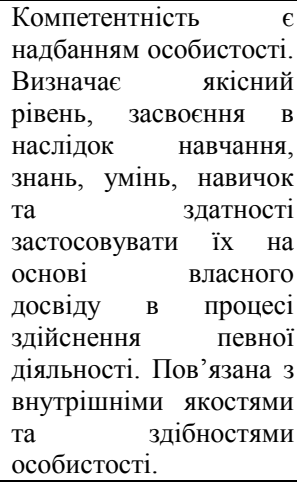 \\
\hline
\end{tabular}


Отже, відмінність в цих поняттях полягає в тому, що термін «компетенція» здебільшого означає добру обізнаність із чим-небудь, характеризує особливості певного виду діяльності з визначеними вимогами до обсягу знань, навичок, умінь особи. Натомість «компетентність» найчастіше пов'язується із досягненням певного рівня професіоналізму через набуття основних компетенцій.

Як правило, до змісту майже будь-якої категорії (поготів, психологічного і соціального аспекту), науковці підходять 3 широких і звужених позицій. Теж і вищезазначеному аспекті. Виокремлюють загальну змістову основу безвідносно конкретного уособлення (рівень знань спеціаліста, коло професійних вимог до нього, необхідний досвід роботи тощо). Виокремлюючи інтегративний характер поняття «компетентність», М. С. Головань слушно зазначає, що в тлумаченнях понять «компетенція» і «компетентність» виражається «когнітивний (знання) i регулятивний (повноваження, закон, статус) аспекти» (Головань, с. 2).

Компетенція проявляється в таких аспектах: коло питань, в яких особа повинна бути обізнана; коло повноважень, делегованих суб'єкту (посадовцю, органу управління, групі і т. п.); досвід, інформаційний ресурс, знання в певній предметній галузі, якими володіє суб’єкт; соціально задана вимога до підготовки особи у певній сфері (Головань, с. 6).

Компетентність $є$ оцінкою якісного рівня здатності особи здійснювати певну діяльність, виконувати професійні функції. Не можна не погодитися 3 С. В. Лейко стосовно того, що компетенція пов'язана 3 компетентністю, «оскільки конкретно окреслює наперед задане коло питань в тій сфері діяльності, з якими повинна бути добре обізнана, тобто компетентна особа» (Лейко, 2013, с. 133).

Поняття «комунікативна компетентність» є однією 3 важливих наукових категорій. Ї̈̈ дослідження розпочалося ще у 60-70-хx pp. XX століття. Дослідження теоретичних i практичних засад формування комунікативної компетентності майбутніх педагогів завжди представляло інтерес для науковців і практиків цієї сфери діяльності. У цьому напрямі вагомим доробком стали праці таких вчених, як Н. Боритко, І. Гапійчук, В. Гриньова, В. Кан-Калік, С. Лейко, Н. Морзе, М. Онищенко та ін.

Поняття «комунікативна компетентність» (від лат. communico - роблю загальним, зв'язую, спілкуюся і competens (competentis) - здатний) означає сукупність знань про норми і правила ведення природної комунікації - діалогу, суперечки, переговорів і т. ін. (Бех, 1998, с. 107). Аналіз наукової літератури зазначеної проблематики показав, що зміст категорії «комунікативна компетенція» та її складових має досить широке тлумачення (табл. 2).

Таблиця 2

\section{Підходи науковців до розгляду змісту поняття} «комунікативна компетентність»

\begin{tabular}{|l|l|}
\hline \multicolumn{1}{|c|}{ Автор, джерело } & \multicolumn{1}{|c|}{ Визначення } \\
\hline $\begin{array}{l}\text { Т. О. Бутенко } \\
\text { (Бутенко, 2011, } \\
\text { с. 15) }\end{array}$ & $\begin{array}{l}\text { Комунікативна компетентність - це володіння комунікативними } \\
\text { знанням, вміннями, навичками та здатність встановлювати } \\
\text { необхідні контакти з іншими людьми }\end{array}$ \\
\hline $\begin{array}{l}\text { I. В. Когут } \\
\text { (Когут, 2015, с. 12) }\end{array}$ & $\begin{array}{l}\text { комунікативна компетентність - уміння встановлювати та } \\
\text { підтимувати необхідні контакти з іншими людьми }\end{array}$ \\
\hline
\end{tabular}




\begin{tabular}{|l|l|}
\hline $\begin{array}{l}\text { I. В. Когут } \\
\text { (Когут, 2015, с. 6) }\end{array}$ & $\begin{array}{l}\text { Комунікативна компетентність - уміння встановлювати та } \\
\text { підтримувати необхідні контакти з іншими людьми; володіння } \\
\text { сукупністю мовних та мовленнєвих умінь; знання норм і правил } \\
\text { спілкування }\end{array}$ \\
\hline $\begin{array}{l}\text { М. М. Вятютнєв } \\
\text { (Вятютнєв, 1977, } \\
\text { с. 40) }\end{array}$ & $\begin{array}{l}\text { комунікативна компетентність - це здатність використовувати } \\
\text { спву творчо, цілеспрямовано, нормативно, у взаємодії зі }\end{array}$ \\
\hline $\begin{array}{l}\text { О. М. Казарцева } \\
\text { (Казарцева, 1999) }\end{array}$ & $\begin{array}{l}\text { комунікативна компетентність - це знання, уміння та навички, } \\
\text { необхідні для розуміння чужих та породження власних програм } \\
\text { мовленнєвої поведінки, адекватних цілям, сферам, ситуаціям } \\
\text { спілкування. }\end{array}$ \\
\hline
\end{tabular}

У проаналізованих роботах наголошується на важливій ролі здібностей людини у формуванні іiі комунікативної компетентності або здатності використовувати мову в тій чи іншій сфері спілкування.

Поява поняття «комунікативна компетентність» пов'язується із розвитком комунікативно орієнтованої лінгвістики. Еволюціонуючи, соціолінгвістика та методики вивчення іноземних мов, як категорії стали тісно співвідноситися з процесами спілкування (Изаренков, 1990).

Досить часто під комунікацією розуміють спілкування, розглядаючи їх як тотожні, нероздільні (Когут, 2015, с. 12-13). Приміром, Д. В. Трубачова категорію «спілкування» визначає як взаємодію між його суб'єктами (Трубачова, 2016, с. 7). У «Філософському енциклопедичному словнику» зміст спілкування визначено як «підтримувати взаємні стосунки, контактувати, розуміти один одного» (Шинкарук та ін., 2002, с. 387).

Проте науковці неодностайні щодо такого підходу і звертають увагу на те, що в психологічній і соціологічній літературі «спілкування» і «комунікація» розглядаються як пересічні, але несинонімічні поняття. Зокрема, К. А. Дмитренко зазначає, що ці поняття мають як загальні ознаки (співвіднесеність із процесами обміну і передачі інформації), так і відмінності (обсяг змісту понять). Виявляючи розбіжності в їх суті, увагу акцентують на «механізмі переводу індивідуального процесу сприйняття і передачі інформації в соціально значущий процес персонального і масового впливу» (Дмитренко, 2012, c. 2).

Переважно, комунікацію розглядають як процес передачі та прийому інформації, а спілкування - як процес самоорганізації. Будь-яка комунікація $\epsilon$ спілкуванням, але не кожне спілкування - комунікацією (Волкова, 2002, с. 411; Яременко, Сліпушко, 2004; Кучай, 2009).

Термін «комунікація» отримав поширення в науковій літературі на початку XX ст. під впливом НТР. Він має технократичний зміст і характеризує стан інформаційного обміну в суспільстві. Використовується для позначення засобів зв'язку будь-яких об'єктів матеріального й духовного світу, процесу передачі інформації від людини до людини, а також передачі й обміну інформацією в суспільстві 3 метою впливу на соціальні процеси (Дмитренко, 2012). У таблиці 3 наведено підходи деяких науковців до розгляду змісту поняття «комунікації». 
Таблиця 3

Тлумачення змісту поняття «комунікації»

у науково-педагогічній літературі

\begin{tabular}{|c|c|}
\hline Автор, джерело & Визначення \\
\hline $\begin{array}{l}\text { Д. В. Трубачова } \\
\text { (Трубачова, 2016, с. 7) }\end{array}$ & Комунікація означає суто інформаційний процес. \\
\hline $\begin{array}{l}\text { Н. Хамітов } \\
\text { (Хамітов, 2002, с. 291) }\end{array}$ & $\begin{array}{l}\text { Комунікація (від лат. сотmunico - повідомлення, зв’язок, } \\
\text { спілкування) - у широкому сенсі це термін, що окреслює } \\
\text { людську взаємодію у світі. }\end{array}$ \\
\hline $\begin{array}{l}\text { I. В. Когут } \\
\text { (Когут, 2015, с. 11) }\end{array}$ & $\begin{array}{l}\text { Комунікація в педагогіці зводиться здебільшого до } \\
\text { технологічного, інформаційного, мовленнєвого аспекту } \\
\text { означення спілкування як суто технологічного засобу } \\
\text { передачі інформації. }\end{array}$ \\
\hline $\begin{array}{l}\text { Н. П. Волкова } \\
\text { (Волкова, 2006) }\end{array}$ & $\begin{array}{l}\text { Комунікація (від лат. сотmunico - робити спільним: } \\
\text { ділитися, наділяти, обмінюватися, радитися, повідомляти, } \\
\text { спілкуватися, приєднувати, зв'язувати, з'єднувати, брати } \\
\text { участь) - це процес та стан взаємодії людини з внутрішнім } \\
\text { і зовнішнім світами. }\end{array}$ \\
\hline $\begin{array}{l}\text { К. А. Дмитренко } \\
\text { (Дмитренко, 2012) }\end{array}$ & $\begin{array}{l}\text { Поняття «комунікація» використовується для позначення } \\
\text { засобів зв'язку будь-яких об'єктів матеріального й } \\
\text { духовного світу, процесу передачі інформації від людини } \\
\text { до людини, а також передачі й обміну інформацією в } \\
\text { суспільстві з метою впливу на соціальні процеси. }\end{array}$ \\
\hline $\begin{array}{l}\text { Л. Баркер } \\
\text { (Мусатов, 2005) }\end{array}$ & $\begin{array}{l}\text { Процес взаємопов'язаних елементів, що працюють разом, } \\
\text { аби досягти необхідного результату або мети. }\end{array}$ \\
\hline $\begin{array}{l}\text { I. В. Когут } \\
\text { (Когут, 2015, с. 6) }\end{array}$ & $\begin{array}{l}\text { Комунікація (від лат. communicatio - єдність, передача, } \\
\text { з’єднання, повідомлення) - це процес обміну інформацією } \\
\text { (фактами, ідеями, поглядами, емоціями тощо) між двома } \\
\text { або більше особами, спілкування за допомогою } \\
\text { вербальних і невербальних засобів із метою передавання } \\
\text { та одержання інформації. }\end{array}$ \\
\hline
\end{tabular}

Як бачимо, поняття «комунікація» має досить широке тлумачення. Одні дослідники вважають категорію «комунікація» базовою, тому що це передача інформації в суспільстві на основі взаємодії між людьми у формі спілкування як обміну знаковими повідомленнями.

Протилежний підхід грунтується на тому, що комунікація виконує роль посередника між індивідуальною i суспільно важливою інформацією. Спілкування між людьми було завжди. Воно характеризує міжособистісну взаємодію людей «під час обміну інформацією пізнавального або афективнооціночного характеру» (Дмитренко, 2012). Це обмін думками, поглядами, почуттями в різних сферах діяльності за допомогою вербальних засобів комунікації. Основними його цілями стає встановлення контакту із суб'єктом і вплив на нього. У структурі спілкування вирізняють комунікацію (обмін інформацією), інтеракцію (організація взаємодії і впливу), перпецію (почуттєве сприйняття як основа взаєморозуміння) (Дмитренко, 2012). Спілкування відбувається у двох формах: формальній та неформальній. Перша $\epsilon$ функціонально-рольовим, професійним спілкуванням, коли люди взаємодіють не як особистості, а як носії певних функцій (визначається мета, завдання, цілі дій). Друга здійснюється на основі особистісних контактів без обмежень і дотримання певних правил поза офіційними відносинами. 
Доволі часто, як зазначає I. В. Когут, «комунікація в педагогіці зводиться здебільшого до технологічного, інформаційного, мовленнєвого аспекту означення спілкування як суто технологічного засобу передачі інформації» (Когут, 2015, с. 11).

Висновки і перспективи подальших розвідок. Отже, на сьогодні немає узгодженості в підходах вчених щодо трактування сутності комунікативної компетентності. Існує неоднозначність, багатоваріантність трактування таких іiі складових, як «компетенція» i «компетентність», «спілкування» i «комунікація». Термін «компетенція» здебільше означає добру обізнаність із чим-небудь, характеризує особливості певного виду діяльності з визначеними вимогами до обсягу знань, навичок, умінь особи. Натомість «компетентність» найчастіше пов'язується із досягненням певного рівня професіоналізму через набуття основних компетенцій, має інтегративний характер. Прослідковується також незрозумілість (ірраціональність) і різноманітність визначень категорій «спілкування» та «комунікація», наявність у них спільних та відмінних рис. Як правило, комунікацію розглядають як процес передачі та прийому інформації, а спілкування - як процес самоорганізації. Зокрема, в педагогіці комунікація найчастіше розглядається як суто технологічний засіб передачі інформації.

Перспективами подальших розвідок $є$ розроблення положень про формування комунікативної компетентності, що $є$ складовою професійнопедагогічної компетенції майбутніх викладачів іноземних мов, врахуванням розмежування змісту явища i форми його прояву не тільки в якості внутрішньої субординації, а й їх діалектичної взаємодії.

\section{СПИСОК ВИКОРИСТАНИХ ДЖЕРЕЛ:}

Лейко, С. (2013). Поняття «компетенція» та «компетентність»: теоретичний аналіз. Педагогічний процес: теорія і практика, [online] Випуск 4, сc. 128-135. Режим доступу : http://nbuv.gov.ua/UJRN/pptp_2013_4_15 [Дата звернення 02 серпня 2018].

Міністерство освіти і науки України, (2014) Стратегія реформування вищої освіти в Україні до 2020 року (проект). Київ. Режим доступу : //http://old.mon.gov.ua/img/zstored/files/HE\%20Re [Дата звернення 02 серпня 2018].

Яременко, В., Сліпушко, О. (2004). В: Новий тлумачний словник украӥнськой мови у трьох томах: Т. 1. Київ : Аконіт, 928 с.

Яременко, В., Сліпушко, О. (2004). В: Новий тлумачний словник украйнськой мови у трьох томах: Т. 2. Київ : Аконіт, 928 с.

Яременко, В., Сліпушко, О. (2004). В: Новий тлумачний словник украӥнськой мови у трьох томах: T. 3. Київ : Аконіт, 864 с.

Бусел, В. (2003). В: Великий тлумачний словник сучасної украйнської мови, Ірпінь : ВТФ «Перун», 1440 с.

Онищенко, М. (2017). Полікультурна компетентність майбутніх перекладачів як важлива складова професійної компетентності. Науковий репозитарій Університету імені Альфреда Нобеля, [online] Режим доступу : http://ir.duan.edu.ua/handle/123456789/963 [Дата звернення 22 березня 2019].

Новиков, А. (2013). В: Педагогика: словарь системы основных понятий. Москва : Издательский центр ИЭТ, 268 с.

Кучай О. (2009). Компетенція і компетентність - відображення цілісності та інтеграційної суті результату освіти. Рідна школа, № 11, сс. 44-48.

Кремень, В. (2014). В: Національний освітній глосарій: вищза освіта. Київ : ТОВ «Видавничий дім «Плеяди», 100 с. 
Хуторський, А. (2003). Ключевые компетенции как компонент личностноориентированной парадигмы образования. Народное образование, № 2, сс. 58-64.

Марущак, О. (2016). Поняття компетентності у педагогічній діяльності. Креативна педагогіка, Житомир, Випуск 11, сс. 97-108.

Калінін, В. (2005). Формування професійної компетентності майбутнього вчителя іноземної мови засобами діалогу культур [автореф. дис. ... канд. пед. наук], $20 \mathrm{c}$.

Головань, М. Компетениія $і$ компетентність: досвід теорії, теорія досвіду, [online] Режим доступу : http://uabs.edu.ua/images/stories/docs/K_VM/Holovan_03.pdf [Дата звернення 04 січня 2019].

Бех, І. (1998). Особистісно-зорієнтоване виховання. Київ : ІЗМН, 204 с.

Бутенко, Т. (2011). Формування комунікативної компетентності майбутніх інженерів у процесі вивчення психолого-педагогічних дисциилін [автореф. дис. ... канд. пед. наук], Вінниця : ДПУ ім. М. Коцюбинського, 22 с.

Когут, I. (2015). Формування професійно-педагогічної комунікативної компетентності майбутнього вчителя [дис. ... канд. пед. наук], Полтава, $250 \mathrm{c}$.

Когут, I. (2015). Формування професійно-педагогічної комунікативної компетентності майбутнього вчителя [автореф дис. ... канд. пед. наук], Полтава, $22 \mathrm{c}$.

Вятютнев, М. (1977). Коммуникативная направленность обучения русскому языку в зарубежных школах. Русский язык за рубежом, № 6, сс. 38-45.

Казарцева, О. (1999). Культура речевого общения: теория и практика обучения, Москва : Флинт, Наука, 496 с.

Изаренков, Д. (1990). Базисные составляющие коммуникативной компетенции и их формирование на продвинутом этапе обучения студентов нефилологов. Русский язык за рубежом, № 4, сс. 54-60.

Трубачова, Д. (2016). Дидактичні умови формування комунікативної діяльності майбутніх учителів іноземної мови в процесі вивчення філологічних дисциилін [автореф дис. ... канд. пед. наук], Київ : Нац. академія педагогічних наук України Ін-т педагогіки, 23 с.

Шинкарук, В. (2002). В: Філософський енциклопедичний словник, Київ : Абрис, 751 с.

Дмитренко, К. (2012). Сутність професійної комунікації у педагогічній освіті. Наукові записки Ніжинського державного університету ім. Миколи Гоголя, [online] №7. Режим доступу: http://nbuv.gov.ua/UJRN/Nzspp_2012_7_4 [Дата звернення 22 березня 2019].

Волкова, Н. (2002). Педагогіка. Київ : Академія, 576 с.

Хамітов, Н. (2002). Комунікації. В: Філософський енциклопедичний словник. Київ : Абрис, 751 с.

Волкова, Н. (2006). Професійно-педагогічна комунікація. Київ : Вид. центр «Академія», $256 \mathrm{c.}$

Мусатов, С. (2005). Педагогічна комунікація: психологічні витоки та особливості. Особисті освітні потреби в системі післядипломної педагогічної освіти, Житомир-Київ : ЖОІППО, 196 с.

\section{REFERENCES:}

Leiko, S. (2013). Poniattia «kompetentsiia» ta «kompetentnist»: teoretychnyi analiz [The Notion of "Competence": Theoretical Analysis]. Pedahohichnyi protses: teoriia $i$ praktyka, [online] Vypusk 4, ss. 128-135. Rezhym dostupu : http://nbuv.gov.ua/UJRN/pptp_2013_4_15 [Data zvernennia 02 serpnia 2018].[in Ukrainian] 
Ministerstvo osvity i nauky Ukrainy, (2014). Stratehiia reformuvannia vyshchoi osvity v Ukraini do 2020 roku (proekt) [The Strategy of Higher Education Reform in Ukraine till 2020 (project)]. Kyiv. Rezhym dostupu : //http://old.mon.gov.ua/img/zstored/files/HE\%20Re [Data zvernennia 02 serpnia 2018]. [in Ukrainian]

Yaremenko, V., Slipushko, O. (2004). V: Novyi tlumachnyi slovnyk ukrainskoi movy u trokh tomakh: T. 1 [New Explanatory Dictionary of the Ukrainian Language: in three volumes: V. 1]. Kyiv: Akonit, 928 s. [in Ukrainian]

Yaremenko, V., Slipushko, O. (2004). V: Novyi tlumachnyi slovnyk ukrainskoi movy u trokh tomakh: T. 2 [New Explanatory Dictionary of the Ukrainian Language: in three volumes: V. 2]. Kyiv : Akonit, 928 s. [in Ukrainian]

Yaremenko, V., Slipushko, O. (2004). V: Novyi tlumachnyi slovnyk ukrainskoi movy u trokh tomakh: T. 3 [New Explanatory Dictionary of the Ukrainian Language: in three volumes: V. 3]. Kyiv : Akonit, 864 s. [in Ukrainian]

Busel, V. (2003). V: Velykyi tlumachnyi slovnyk suchasnoi ukrainskoi movy [Big Explanatory Dictionary of Modern Ukrainian Language]. Irpin : VTF "Perun", 1440 s. [in Ukrainian]

Onyshchenko, M. (2017). Polikulturna kompetentnist maibutnikh perekladachiv yak vazhlyva skladova profesiinoi kompetentnosti [Polycultural Competence of Future Translators as an Important Component of Professional Competence]. Naukovyi repozytarii Universytetu imeni Alfreda Nobelia, [online] Rezhym dostupu : http://ir.duan.edu.ua/handle/123456789/963 [Data zvernennia 22 bereznia 2019]. [in Ukrainian]

Novikov. A. (2013). V: Pedagogika: slovar sistemy osnovnykh ponyatiy [Pedagogy: a Dictionary of Basic Concepts]. Moskva : Izdatelskiy tsentr IET. 268 s. [in Russian]

Kuchai O. (2009). Kompetentsiia i kompetentnist - vidobrazhennia tsilisnosti ta intehratsiinoi suti rezultatu osvity [Competence and Competency - Reflection of the Integrity and Integrative Nature of the Result of Education]. Ridna shkola, No 11, ss. 4448. [in Ukrainian]

Kremen, V. (2014). V: Natsionalnyi osvitnii hlosarii: vyshcha osvita [National Educational Glossary: Higher Education]. Kyiv : TOV "Vydavnychyi dim "Pleiady", 100 s. [in Ukrainian]

Khutorskiy. A. (2003). Klyuchevyye kompetentsii kak komponent lichnostnooriyentirovannoy paradigmy obrazovaniya [Key Competencies as a Component of the Student-centered Education Paradigm]. Narodnoye obrazovaniye, No 2. ss. 58-64. [in Russian]

Marushchak, O. (2016). Poniattia kompetentnosti u pedahohichnii diialnosti [Concept of Competence in Pedagogical Activity]. Kreatyvna pedahohika, Zhytomyr, Vypusk 11, ss. 97-108. [in Ukrainian]

Kalinin, V. (2005). Formuvannia profesiinoi kompetentnosti maibutnoho vchytelia inozemnoi movy zasobamy dialohu kultur [Formation of Professional Competence of the Future Teacher of a Foreign Language by Means of Dialogue of Cultures] [avtoref. dys. ... kand. ped. nauk], $20 \mathrm{~s}$. [in Ukrainian]

Holovan, M. Kompetentsiia $i$ kompetentnist: dosvid teorii, teoriia dosvidu [Competence and Competency: Experience of Theory, Theory of Experience], [online] Rezhym dostupu : http://uabs.edu.ua/images/stories/docs/K_VM/Holovan_03.pdf [Data zvernennia 04 sichnia 2019]. [in Ukrainian]

Bekh, I. (1998). Osobystisno-zoriientovane vykhovannia [Personally-oriented Education]. Kyiv : IZMN, 204 s. [in Ukrainian]

Butenko, T. (2011). Formuvannia komunikatyvnoi kompetentnosti maibutnikh inzheneriv u protsesi vyvchennia psykholoho-pedahohichnykh dystsyplin [Formation of Communicative Competence of Future Engineers in the Process of Studying 
Psychological and Pedagogical disciplines] [avtoref. dys. ... kand. ped. nauk], Vinnytsia : DPU im. M. Kotsiubynskoho, 22 s. [in Ukrainian]

Kohut, I. (2015). Formuvannia profesiino-pedahohichnoi komunikatyvnoi kompetentnosti maibutnoho vchytelia [Formation of Vocational and Pedagogical Communicative Competence of the Future Teacher] [dys. ... kand. ped. nauk], Poltava, 250 s. [in Ukrainian]

Kohut, I. (2015). Formuvannia profesiino-pedahohichnoi komunikatyvnoi kompetentnosti maibutnoho vchytelia [Formation of Vocational and Pedagogical Communicative Competence of the Future Teacher] [avtoref dys. ... kand. ped. nauk], Poltava, 22 s. [in Ukrainian]

Vyatyutnev. M. (1977). Kommunikativnaya napravlennost obucheniya russkomu yazyku v zarubezhnykh shkolakh [Communicative Orientation of Teaching Russian in Foreign Schools]. Russkiy yazyk za rubezhom. No 6. ss. 38-45. [in Russian]

Kazartseva. O. (1999). Kultura rechevogo obshcheniya: teoriya $i$ praktika obucheniya [Speech Communication Culture: Theory and Practice of Learning]. Moskva : Flint. Nauka. 496 s. [in Russian]

Izarenkov. D. (1990). Bazisnyye sostavlyayushchiye kommunikativnoy kompetentsii i ikh formirovaniye na prodvinutom etape obucheniya studentov nefilologov [Basic Components of Communicative Competence and their Formation at an Advanced Stage of Training of Non-philology Students]. Russkiy yazyk za rubezhom. No 4. ss. 5460. ]in Russian]

Trubachova, D. (2016). Dydaktychni umovy formuvannia komunikatyvnoi diialnosti maibutnikh uchyteliv inozemnoi movy $v$ protsesi vyvchennia filolohichnykh dystsyplin [Didactic Conditions for the Formation of Communicative Activity of Future Teachers of a Foreign Language in the Process of Studying Philological Disciplines] [avtoref dys. ... kand. ped. nauk], Kyiv : Nats. akademiia pedahohichnykh nauk Ukrainy In-t pedahohiky, 23 s. [in Ukrainian]

Shynkaruk, V. (2002) .V: Filosofskyi entsyklopedychnyi slovnyk [Philosophical Encyclopedia Dictionary], Kyiv : Abrys, 751 s. [in Ukrainian]

Dmytrenko, K. (2012) Sutnist profesiinoi komunikatsii u pedahohichnii osviti [The Essence of Professional Communication in Pedagogical Education]. Naukovi zapysky Nizhynskoho derzhavnoho universytetu im. Mykoly Hoholia [online] №7. Rezhym dostupu: http://nbuv.gov.ua/UJRN/Nzspp_2012_7_4 [Data zvernennia 22 bereznia 2019]. [in Ukrainian] Ukrainian]

Volkova, N. (2002). Pedahohika [Pedagogy]. Kyiv : Akademiia, 576 s. [in

Khamitov, N. (2002). Komunikatsii [Communications]. V: Filosofskyi entsyklopedychnyi slovnyk. Kyiv : Abrys, $751 \mathrm{~s}$. [in Ukrainian]

Volkova, N. (2006). Profesiino-pedahohichna komunikatsiia [Professionalpedagogical Communication]. Kyiv : Vyd. tsentr «Akademiia», $256 \mathrm{~s}$. [in Ukrainian]

Musatov, S. (2005). Pedahohichna komunikatsiia: psykholohichni vytoky ta osoblyvosti [Pedagogical Communication: Psychological Origins and Peculiarities]. Osobysti osvitni potreby $v$ systemi pisliadyplomnoi pedahohichnoi osvity, Zhytomyr-Kyiv : ZhOIPPO, 196 s. [in Ukrainian]

\title{
COMMUNICATIVE COMPETENCE OF FUTURE TEACHERS OF FOREIGN LANGUAGES AS A SUBJECT OF SCIENTIFIC RESEARCH
}

\author{
Serhii Haletskyi \\ Lecture at the Department of Business Communication \\ The National University of Ostroh Academy, \\ Ostroh, Ukraine
}


ORCID: 0000-0001-6532-3108

e-mail: sergii.galetskyi@oa.edu.ua

\begin{abstract}
The article deals with approaches to the interpretation of communicative competence. It was noted that communicative competence is an integral part of the vocational and pedagogical competence of English language teachers. The level of formation of knowledge, communicative skills, skills of future specialists has a decisive influence on the ability to implement them in the pedagogical process, establishing contacts, education of modern youth, successful business in the business environment. Dynamic scientific, technical and social development, the modern computer world, the globalization of the socio-economic space, the considerable intensity of business contacts not only extend the horizons of opportunities for a person, but also raise new demands on its educational level, stimulate further improvement of forms, methods, techniques , knowledge transfer technologies. The requirement of time is the constant increase of professional skills, personal communicative activity. Through communications, information is transmitted, business and personal contacts are established, professional and business mutual understanding is provided, new thinking, skills, knowledge, skills, needs are formed. The general and distinctive features in such components as "competence" and "competency", "conversation" and "communication" are found out. It is emphasized on the need for a clearer use of such general scientific definitions as "term", "concept", "category". It is important to distinguish in the internal organization the phenomenon of the ratio of concepts "general" and "partial". It characterizes the distinction between the content of the phenomenon and the form of its manifestation not only as an internal subordination, but also their dialectical interaction. The process of development of the phenomenon is manifested in the inextricability and interconversion of one category to another. It is concluded that the lack of consistency in the approaches of scientists to the interpretation of the essence, constituents, the ratio of many concepts is often associated with the fuzzy distinction in the internal organization of the phenomenon of the ratio of concepts "general" and "partial".
\end{abstract}

Key words: communicative competence, competence, competency, communication, converse, term, concept, category.

Стаття надійшла до редакиії 19.04.2019p. 